лены причинно-следственные связи низкой ферментативной активности у больных АФС и наличия высоких титров антител к кардиолипину и $\beta_{2}$-гликопротеина-1. Снижение уровня параоксаназы является предиктором раннего развития структурно-функциональных изменений в сосудах больных АФС.

Ключевые слова: параоксаназа, антифосфолипидный синдром, метаболические факторы риска, структурнофункциональные изменения сосудов.

\title{
THE ROLE OF PARAOXONASE IN THE FORMATION OF ATHEROSCLEROTIC CHANGES IN THE VESSELS OF PATIENTS WITH ANTIPHOSPHOLIPID SYNDROME
}

\section{S.V. Shevchuk, Ya.S. Seheda, O.V. Shevchuk}

Abstract. As a result of studies carried out by the authors a significant reduction of the serum paraoxonase activity in a Ukrainian population of patients with antiphospholipid syndrome (APS) has been demonstrated. The main factors that affect the enzyme level were the male gender, age, arterial hypertension, tobacco smoking, abnormalities of lipid metabolism. The course of the disease and obesity did not play a significant role. Cause-and-effect relationships between a low enzymatic activity in patients with APS and the presence of high titers of anticardiolipin antibodies and beta-2 glycoprotein 1 antibodies has been established. A reduction of paraoxonaze level is a predictor of an early development of structural and functional changes in the blood vessels of patients with APS.

Key words: paraoxonaze, antiphospholipid syndrome, metabolic risk factors, structural and functional changes of blood vessels.

M.I. Pyrohov National Medical University (Vinnytsia)

Рецензент - д. мед. н. Т.О. Ілащук

Buk. Med. Herald. - 2013. - Vol. 17, № 1 (65). - P. 137-144

Надійшла до редакції 24.01.2013 року

(ㄷ) С.В. Шевчук, Ю.С. Сегеда, О.В. Шевчук, 2013

УДК 618.36-002

О.П. Шендерюк

\section{ФЕРМЕНТНА АКТИВНІСТЬ ТА КОНЦЕНТРАЦІЯ ПЛАЦЕНТАРНОЇ ЛУЖНОЇ ФОСФАТАЗИ У ТРОФОБЛАСТІ ХОРІАЛЬНИХ ВОРСИНОК ПЛАЦЕНТИ ПРИ ЗАПАЛЕННІ ПОСЛІДУ (ГІСТОХІМІЧНЕ ТА ІМУНОГІСТОХІМІЧНЕ ДОСЛІДЖЕННЯ)}

Буковинський державний медичний університет, м. Чернівці

Резюме. У статті автор надає кількісні результати власних гістохімічних та імуногістохімічних досліджень ферментної активності та концентрації специфічного плацентарного білка «плацентарної лужної фосфа-

Вступ. Запалення посліду є можливою причиною плацентарної недостатності $[1,2]$. Одним із найбільш важливих проявів останньої можуть бути порушення стану білків хоріальних ворсинок плаценти [2]. Слід зазначити, що на даний час при запаленні посліду не вивчено стану в такого специфічного білка трофобласта, як плацентарна лужна фосфатаза.

Термінологічна одиниця «лужна фосфатаза» (ЛФ) є груповим поняттям і включає в себе ферментні молекули з різною хімічною будовою, спільною ознакою яких є здатність відщеплювати фосфат від багатьох типів молекул, при цьому ці ферменти проявляють найбільшу активність у лужному середовищі. Плацентарна ЛФ є специфічним для плаценти білком і відіграє важливу роль у функціях плаценти [2]. Концентрацію плацентарної ЛФ можна визначити імуногістохімічним методом, а ферментну активність - завдяки (c) О.П. Шендерюк, 2013 144 тази» у трофобласті хоріальних ворсинок при різних видах запалення посліду.

Ключові слова: плацентарна лужна фосфатаза, запалення посліду.

особливості цього білка, яка полягає в тому, що плацентарна ЛФ є термостабільним ферментом, тобто iї ферментні властивості, на відміну від інших ЛФ плаценти, зберігаються навіть після термічної обробки.

Мета дослідження. Встановити кількісні параметри активності та концентрації специфічного плацентарного білка «плацентарної лужної фосфатази» в трофобласті хоріальних ворсинок при різних видах запалення посліду.

Матеріал і методи. Шматочки плаценти фіксували 24 години в нейтральному забуференому за Ліллі $10 \%$ розчині формаліну, після зневоднювання матеріал заливали у парафін-віск. Гістологічні зрізи 5 мкм використовували для постановки імуногістохімічної методики 3 антитілами проти специфічного плацентарного білка «плацентарної ЛФ». У зазначеній імуногістохімічній методиці використовувалася стрептавідинбіо- 
тинова система візуалізації антитіл LSAB2 (пероксидазна мітка + діамінобензидин) виробника Dako (Denmark). Про концентрацію плацентарної ЛФ судили на основі величини оптичної густини специфічного імуногістохімічного забарвлення в умовних одиницях оптичної густини (від 0 - відсутність забарвлення, абсолютна прозо- рість, до 1 - максимальне забарвлення, абсолютна непрозорість), яку вимірювали на цифрових монохромних копіях зображення зондовим методом шляхом комп'ютерної мікроденситометрії за допомогою комп'ютерної програми GIMP (ліцензія GPL, 2012). Ферментативну активність плацентарної ЛФ визначали на заморожених зрізах методом

Таблиця

\section{Оптична густина (в ум. од.опт.густини) специфічного забарвлення цитоплазми трофобласта хоріальних ворсинок плаценти з визначенням концентрації та ферментної активності плацентарної лужної фосфатази при різних видах запалення посліду та фізіологічній вагітності $(\mathrm{X} \pm \mathrm{Sx})$}

\begin{tabular}{|c|c|c|}
\hline \multirow[b]{2}{*}{ Різновид запалення посліду } & \multicolumn{2}{|c|}{ Методи } \\
\hline & $\begin{array}{c}\text { Імуногістохімічне визначення } \\
\text { концентрації плацентарної лужної } \\
\text { фосфатази. } \\
\text { Комп’ютерна мікроденситометрія } \\
\text { (ум.од.опт.густини) }\end{array}$ & $\begin{array}{c}\text { Гістохімічне визначення ферментної } \\
\text { активності плацентарної лужної фос- } \\
\text { фатази методом азосполучення. } \\
\text { Комп’ютерна мікроденситометрія } \\
\text { (ум.од.опт.густини) }\end{array}$ \\
\hline Фізіологічна вагітність (n=30) & $0,244 \pm 0,0020$ & $0,238 \pm 0,0022$ \\
\hline $\begin{array}{c}\text { Гострий плацентарний хоріонам- } \\
\text { ніоніт }(\mathrm{n}=24)\end{array}$ & $\begin{array}{l}0,221 \pm 0,0024 \\
\mathrm{P}<0,001\end{array}$ & $\begin{array}{l}0,106 \pm 0,0014 \\
\mathrm{P}<0,001\end{array}$ \\
\hline $\begin{array}{c}\text { Гострий парієтальний хоріонамні- } \\
\text { оніт }(\mathrm{n}=16)\end{array}$ & $\begin{array}{c}0,229 \pm 0,0029 \\
\mathrm{P}=0,004\end{array}$ & $\begin{array}{l}0,108 \pm 0,0023 \\
\mathrm{P}<0,001\end{array}$ \\
\hline $\begin{array}{c}\text { Хронічний плацентарний } \\
\text { хоріонамніоніт }(\mathrm{n}=19)\end{array}$ & $\begin{array}{l}0,238 \pm 0,0030 \\
\quad P>0,050\end{array}$ & $\begin{array}{l}0,234 \pm 0,0020 \\
\quad \mathrm{P}>0,050\end{array}$ \\
\hline $\begin{array}{l}\text { Хронічний парієтальний } \\
\text { хоріонамніоніт }(\mathrm{n}=14)\end{array}$ & $\begin{array}{l}0,240 \pm 0,0032 \\
\mathrm{P}>0,050\end{array}$ & $\begin{array}{l}0,235 \pm 0,0030 \\
\quad P>0,050\end{array}$ \\
\hline $\begin{array}{c}\text { Гострий базальний децидуїт } \\
\qquad(\mathrm{n}=19)\end{array}$ & $\begin{array}{l}0,224 \pm 0,0028 \\
\mathrm{P}=0,001\end{array}$ & $\begin{array}{l}0,114 \pm 0,0032 \\
\quad \mathrm{P}<0,001\end{array}$ \\
\hline $\begin{array}{l}\text { Хронічний базальний децидуїт } \\
\qquad(\mathrm{n}=23)\end{array}$ & $\begin{array}{l}0,241 \pm 0,0027 \\
\mathrm{P}>0,050\end{array}$ & $\begin{array}{l}0,233 \pm 0,0027 \\
\quad P>0,050\end{array}$ \\
\hline $\begin{array}{l}\text { Гострий вілузит з інтервілузитом } \\
\qquad(\mathrm{n}=14)\end{array}$ & $\begin{array}{l}0,184 \pm 0,0022 \\
\mathrm{P}<0,001\end{array}$ & $\begin{array}{l}0,094 \pm 0,0011 \\
\mathrm{P}<0,001\end{array}$ \\
\hline Гострий фунікуліт (n=12) & $\begin{array}{l}0,242 \pm 0,0028 \\
\quad \mathrm{P}>0,050\end{array}$ & $\begin{array}{l}0,236 \pm 0,0023 \\
\mathrm{P}>0,050\end{array}$ \\
\hline
\end{tabular}

Примітка. Р - вірогідність розбіжності в середніх тенденціях від групи дослідження «фізіологічна вагітність» за непарним двобічним критерієм Стьюдента

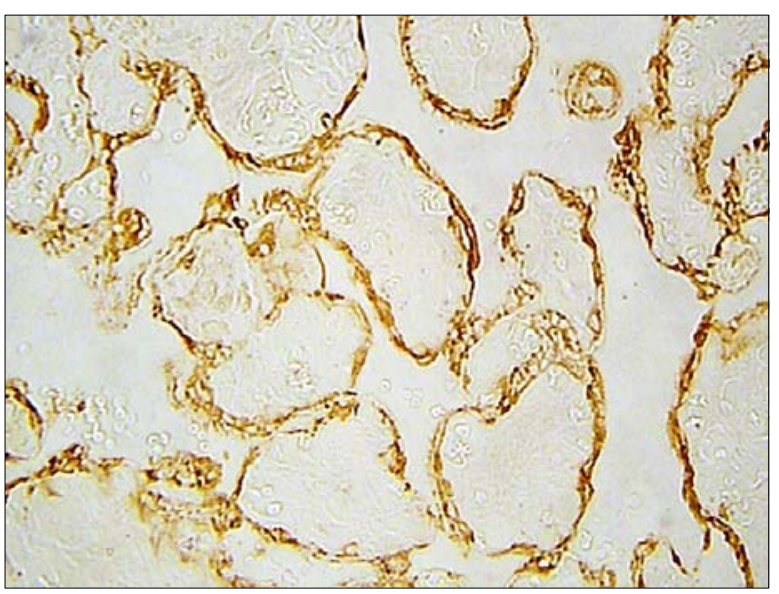

Рис. 1. Мікрофотографія хоріальних ворсинок плаценти при фізіологічній вагітності. Імуногістохімічна методика 3 первинними антитілами проти плацентарної лужної фосфатази та візуалізацією первинних антитіл стрептавідин-біотиновим методом з використанням діамінобензидину. Об. $20^{\mathrm{x}}$, Ок. $10^{\mathrm{x}}$

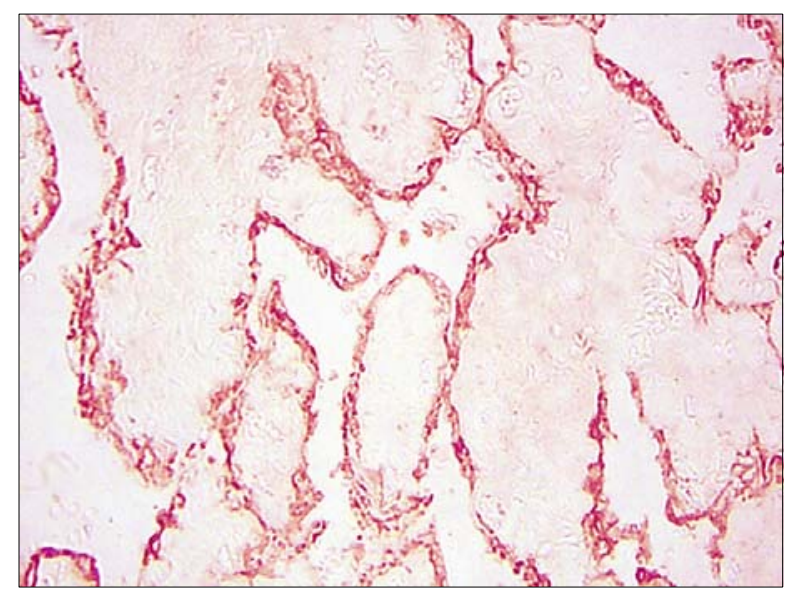

Рис. 2. Мікрофотографія хоріальних ворсинок плаценти при фізіологічній вагітності. Гістохімічна методика визначення ферментної активності плацентарної лужної фосфатази методом азосполучення. Об. $20^{\mathrm{x}}$, Ок. $10^{\mathrm{x}}$ 
азосполучення після термічної обробки зрізів у термостаті при $58^{\circ} \mathrm{C}$. Інтенсивність гістохімічного забарвлення оцінювали вищевказаним способом за допомогою комп’ютерної програми GIMP.

Для кожного показника вираховували середню арифметичну та іiї похибку. Порівняння між групами дослідження робили за допомогою двох методів - параметричний двобічний непарний критерій Стьюдента та непараметричний критерій MannWhitney у середовищі комп'ютерної програми PAST (вільна ліцензія) [3]. Попередньо виконували перевірку на нормальність у вибірках методом Shapiro-Wilki за допомогою комп'ютерної програми PAST. Назви груп дослідження та величина кожної статистичної вибірки вказані в таблиці.

Результати дослідження та їх обговорення. Рисунки 1 та 2 з мікрофотографіями дають уявлення про те, як забарвлюються структури хоріальних ворсинок плаценти при застосованих мікроскопічних методиках. Слід відзначити, що як імуногістохімічним, так і гістохімічним методами позитивне забарвлення на плацентарну ЛФ виявлялося тільки в трофобласті всіх варіантів хоріальних ворсинок. Це забарвлення мало нерівномірний гранулярний характер і в межах трофобласта локалізувалося тільки в його цитоплазмі, в ядрах забарвлення не відмічено.

Середні цифри оптичної густини забарвлення за групами дослідження вказані в таблиці.

Наведені в таблиці дані виявили цікаву закономірність, яка полягала в тому, що за виключенням такого виду гострого запалення посліду, як гострий фунікуліт, при інших видах гострого запалення посліду знижувалася як концентрація, так і ферментативна активність плацентарної ЛФ, тоді, коли при хронічних формах запалення посліду статистично вірогідного зниження концентрації і ферментативної активності плацентарної ЛФ не виявлено.

Вирахування середнього відсотка зниження концентрації та ферментативної активності плацентарної ЛФ у трофобласті хоріальних ворсинок при гострих формах запалення посліду показало наступне: порівняно 3 групою дослідження «Фізіологічна вагітність» інтенсивність забарвлення, яке відповідає концентрації плацентарної ЛФ (імуногістохімічне дослідження), була в середньому знижена: у групі дослідження «Гострий плацентарний хоріонамніоніт» - на 9,4 \%, у групі дослідження «Гострий парієтальний хоріонамніоніт»на 6,2 \%, у групі дослідження «Гострий базальний децидуїт» - на $8,2 \%$, у групі дослідження «Гострий вілузит з інтервілузитом» - на 25,6 \%.
Порівняно 3 групою дослідження «Фізіологічна вагітність» інтенсивність забарвлення, яке відповідає ферментативній активності плацентарної ЛФ (гістохімічне дослідження) була в середньому знижена: у групі дослідження «Гострий плацентарний хоріонамніоніт» - на 56,6 \%, у групі дослідження «Гострий парієтальний хоріонамніоніт» - на $55,7 \%$, у групі дослідження «Гострий базальний децидуїт» - на 53,3 \%, у групі дослідження «Гострий вілузит з інтервілузитом» - на 61,5\%, тобто більше, ніж удвічі.

Наведені відсоткові дані вказують на те, що при гострих формах запалення посліду ферментна активність плацентарної ЛФ знижується більш інтенсивно, ніж концентрація цього білка, що може свідчити про те, що хоча має місце порушення продукції плацентарної ЛФ, все ж відбувається і зміна молекул цього білка, яка призводить до зменшення здатності плацентарної ЛФ відщеплювати фосфат від субстрату.

\section{Висновки}

1. При гострих формах запалення посліду, за виключенням гострого фунікуліту, у трофобласті хоріальних ворсинок суттєво знижується як концентрація плацентарної лужної фосфатази, так і їі ферментативна активність, причому у відсотковому вимірюванні активність ферменту знижується більш сильно, ніж його концентрація.

2. При хронічних формах запалення посліду в трофобласті хоріальних ворсинок не відмічається статистично значимого зниження концентрації чи ферментативної активності плацентарної лужної фосфатази.

Перспектива подальших досліджень полягає в подальшому визначенні конкретних величин діагностичної цінності показників концентрації та ферментативної активності плацентарної лужної фосфатази в трофобласті хоріальних ворсинок плаценти при різних видах запалення посліду.

\section{Література}

1. Цинзерлинг В.А. Перинатальные инфекции (Вопросы патогенеза, морфологической диагностики и клинико-морфологических сопоставлений). Практическое руководство / В.А. Цинзерлинг, В.Ф. Мельникова. - СПб.: Элби СПб, 2002. - 352 с.

2. Benirschke K. Pathology of the Human Placenta / K. Benirschke, P. Kaufmann, R.N. Baergen. - [5 rd. ed]. - New York: Springer, 2006. - 1050 p.

3. Hammer O. PAST: Paleontological Statistics. Reference Manual / O.Hammer, D.A.T.Harper, P.D. Ryan // Oslo: University of Oslo, 2012. - 284 p.

\section{ФЕРМЕНТНАЯ АКТИВНОСТЬ И КОНЦЕНТРАЦИЯ ПЛАЦЕНТАРНОЙ ЩЕЛОЧНОЙ ФОСФАТАЗЫ В ТРОФОБЛАСТЕ ХОРИАЛЬНЫХ ВОРСИНОК ПЛАЦЕНТЫ ПРИ ВОСПАЛЕНИИ ПОСЛЕДА (ГИСТОХИМИЧЕСКОЕ И ИММУНОГИСТОХИМИЧЕСКОЕ ИССЛЕДОВАНИЕ)}

\section{А.П. Шендерюк}

Резюме. В статье автор приводит количественные результаты собственных гистохимических и иммуногистохимических исследований ферментной активности и концентрации специфического плацентарного белка «плацентарной 
щелочной фосфатазы» в трофобласте хориальных ворсинок при различных видах воспаления последа.

Ключевые слова: плацентарная щелочная фосфатаза, воспаление последа.

\section{ENZYMATIC ACTIVITY AND THE CONCENTRATION OF PLACENTAL ALKALINE PHOSPHATASE IN THE TROPHOBLAST OF CHORIAL VILLI OF THE PLACENTA IN CASE OF AFTERBIRTH INFLAMMATION (A HISTOCHEMICAL AND IMMUNOHISTOCHEMICAL INVESTIGATION)}

\section{O.P. Shenderiuk}

Abstract. The author presents quantitative results of his own histochemical and immunohistochemical investigations of the enzymatic activity and the concentration of the specific placental protein «placental alkaline phosphatase» in the trophoblast of chorial villi with different varieties of afterbirth inflammation in this paper.

Key words: placental alkaline phosphatase, afterbirth inflammation.

Bukovinian State Medical University (Chernivtsi)

Рецензент - проф. О.А. Андрієць

Buk. Med. Herald. - 2013. - Vol. 17, № 1 (65). - P. 144-147

Надійшла до редакції 18.01.2013 року

(c) О.П. Шендерюк, 2013

УДК 616.24-002-085.281

О.А. Яковлева, Н.В. Щербенюк

\section{СТРУКТУРА НАЗНАЧЕНИЙ ЛЕКАРСТВЕННЫХ СРЕДСТВ ПРИ ЛЕЧЕНИИ НЕГОСПИТАЛЬНОЙ ПНЕВМОНИИ В СТАЦИОНАРАХ (В ТЕЧЕНИЕ 2011 ГОДА)}

Винницкий национальный медицинский университет им. Н.И. Пирогова

Резюме. С целью изучения реальной практики использования лекарственных средств при лечении негоспитальной пневмонии в стационарах г. Винницы был проведен ретроспективный анализ 760 медицинских карт стационарных больных. Результаты анализа показали, что для лечения негоспитальной пневмонии больные получали в среднем $10,18 \pm 0,13$ лекарственных препаратов. Антибактериальные препараты для системного применения получали все 760 пациентов, в среднем одному больному их назначалось $2,51 \pm 0,03$ (от 1 до

Введение. Негоспитальная пневмония (НП) относится к заболеваниям, имеющим важное медико-социальное значение, поскольку ее высокая распространенность и проблемы, связанные с диагностикой и лечением, определяют значительные экономические потери, которые государство несет в связи с этой патологией [6]. Накопленные к настоящему времени данные служат основой для периодического обновления национальных рекомендаций по ведению больных с НП. Основная цель клинических рекомендаций - улучшение диагностики и качества лечения больных с НП в амбулаторной практике и стационаре [5].

Применение стандартов и протоколов лечения в клинической фармакологии призвано регламентировать в некоторой степени субъективную составляющую клинического мышления врача. Однако этот аспект не может быть полностью устранен, с учетом различной психологии врачевания, опытом, стажем, уровнем знаний

(C) О.А. Яковлева, Н.В. Щербенюк, 2013
7). Достаточно часто применялись нестероидные противовоспалительные средства $(38,0 \%)$, сульфокамфокаин $(29,7 \%)$, биогенные стимуляторы $(23,2 \%)$, витамины $(8,6 \%)$. Полученные данные свидетельствуют о полипрагмазии и могут служить основой планирования комплекса мероприятий по совершенствованию фармакотерапии негоспитальных пневмоний.

Ключевые слова: негоспитальная пневмония, фармакоэпидемиология, фармакотерапия.

современных врачей. Поэтому тактика выбора необходимой фармакотерапии отражает ее многофакторную мозаику, которая должна объединить умения врача, свойства лекарственного препарата и индивидуальность пациента.

В какой мере эти три составляющие сочетаются в реальной врачебной практике и приводят к результатам эффективной фармакотерапии - можно изучить фармакоэпидемиологическим анализом.

Цель исследования. Получить объективные данные о практике применения лекарственных средств (ЛС) при лечении НП в стационарных условиях и оценить рациональность применяемых режимов терапии с точки зрения современных стандартов и клинической фармакологии.

Материал и методы. Для ретроспективного анализа отбирались медицинские карты стационарных больных, в возрасте от 16 до 65 лет, находившихся на лечении в пульмонологических отделениях г. Винницы с диагнозом НП с 01.01.11. по 